\title{
Change of Extracellular Polymeric Substances Composition of Thiobacillus thioparus in Presence of Sulfur and Steel
}

\author{
Mariia Boretska ${ }^{1 \# *}$, Sören Bellenberg ${ }^{2 \#}$, Olena Moshynets ${ }^{3}$, lanina Pokholenko ${ }^{3}$ and Wolfgang Sand \\ ${ }^{1}$ D.K. Zabolotny Institute of Microbiology and Virology of the NAS of Ukraine, Kyiv, Zabolontogo str, 154, Ukraine \\ ${ }^{2}$ Universität Duisburg-Essen, Aquatic Biotechnology, Biofilm Centre, Universitätsstr 5, Essen, Germany \\ ${ }^{3}$ Institute of Molecular Biology and Genetics NAS of Ukraine, Zabolotnogo str, 150, Kyiv, Ukraine \\ \#Mariia Boretska and Sören Bellenberg contributed equally to this work.
}

\begin{abstract}
The process of microbially influenced corrosion (MIC) of metallic underground constructions is often related with biofilm formation and metabolic activity of sulfur cycle bacteria. The extracellular polymeric substances (EPS) produced by these bacteria in biofilms on metallic surfaces establish the interfacial reaction space in which relevant corrosion processes occur. The EPS composition of the sulfur oxidizing bacterium Thiobacillus thioparus DSM 505 varies according to growth conditions. Presence of elemental sulfur and mild steel are demonstrated here as stimulants for variation of the EPS composition. The distribution of sugar moieties in the EPS of planktonic and biofilm grown cells of Thiobacillus thioparus DSM 505 was observed by fluorescently labeled lectin binding assays. The strongest signal was found with the PWM lectin (Pokeweed, Phytolacca americana) specific for Poly$\mathrm{N}$-Acetylglucosamine (PNAG). Cell associated proteins, visualized by Thiazine Red staining, were observed in the planktonic growth mode. Low amounts of EPS proteins from planktonic were detected. The observed influence of elemental sulfur and mild steel on the EPS composition in biofilm forming cells can be suggested to have a pivotal role in interfacial processes such as (bio) corrosion. Understanding factors that mediate changes in the composition and surface associated structural features of EPS as a consequence of working materials may help to develop a new strategy for biocorrosion prevention.
\end{abstract}

Keywords: Biofilm; Extracellular polymeric substances (EPS); Lectin; Biocorrosion; Biodeterioration; Ferrosphere

\section{Introduction}

Bacteria can form biofilms on almost every natural and artificial surface. Biogenic substrata, such as cover tissues of plants, animal skin, other bacteria and abiotic surfaces or interfaces such as surfaces of minerals or phase boundaries of water/air or air/solid materials harbor biofilms [1-4]. Unwanted biofilm formation can cause damages to constructions as well as to industrial plants and transport systems [5]. The process of microbially influenced corrosion (MIC) is an example of biofilm formation where microorganisms become corrosionrelevant [6]. Iron, manganese and sulfur cycle bacteria are often found connected with these corrosion cases since the redox reactions carried out by these microorganisms drive materials deterioration. At metallic gas pipeline constructions, soil bacteria such as Thiobacillus thioparus appear in close contact with metal surfaces. This interface between the metal surfaces of the construction in contact with soil is termed ferrosphere [7]. The strictly autotrophic sulfur bacterium $T$. thioparus is a relevant part of a corrosion favoring community, which has been found to be present in the ferrosphere, and has the ability to oxidize sulfur compounds such as elemental sulfur, thiosulfate, thiocyanate and polythionates. These compounds occur in industrial processes such as extraction of sulfur compounds from natural gas or the anaerobic treatment of sulfate-containing waste water [8-10]. During the processing of natural gas the wastewater generated contains up to $3.0 \mathrm{~g} \mathrm{l}^{-1}$ thiosulfate [11]. Due to oxidation of reduced sulfur compounds by sulfur oxidizing bacteria elemental sulfur and sulfuric acid are generated. Corrosion relevant sulfate reducing prokaryotes may establish a closed sulfur cycle in microaerophilic and anaerobic niches in the ferrosphere [7]. Acidification in some microniches may promote the development of biofilms of extremely acidophilic bacteria like Acidithiobacillus thiooxidans and Acidithiobacillus ferrooxidans.

The role of elemental sulfur $\left(\mathrm{S}^{\circ}\right)$ in biocorrosion processes is established [12]. According to the unified electron-transfer hypothesis, elemental sulfur particles immobilized by extracellular polymeric substances (EPS) on the mild steel surface in bacterial biofilms could act as an anode [6,7]. As mentioned [13], EPS localize both, cells and metabolic products of the biofilm, and retain them in close proximity. The EPS components are polysaccharides, proteins, lipopolysaccharides and extracellular DNA. The polysaccharides are often the major fraction of the EPS matrix and fluorescently labeled lectins can be used as probes to investigate carbohydrate distribution within a biofilm structure [13]. Also carboxyl group residues present in the EPS-matrix can complex metal ions. Metal cations are therefore removed them from the solubility equilibrium favoring further material dissolution processes [6]. EPS may additionally be corrosive as complexed $\mathrm{Fe}^{3+}$ or manganese oxides may act as electron scavengers catalyzing cathodic reactions on metal or mineral surfaces. The importance of EPS in the biocorrosion processes has not been well determined yet, however many aspects suggest their pivotal role for interfacial processes such as (bio) corrosion $[6,14,15]$.

EPS produced by bacteria determine the first step of biofilm formation, the attachment of single cells $[16,17]$. EPS can be considered

${ }^{*}$ Corresponding author: Mariia Boretska, Department of General and Soil Microbiology, Zabolotny Institute of Microbiology and Virology of the NAS of Ukraine, Ukraine, Tel: +38 (044) 52611 79; Fax: +38(044) 52623 79; E-mail maria.boretska@gmail.com

Received June 04, 2013; Accepted July 02, 2013; Published July 05, 2013

Citation: Boretska M, Bellenberg S, Moshynets O, Pokholenko I, Sand W (2013) Change of Extracellular Polymeric Substances Composition of Thiobacillus thioparus in Presence of Sulfur and Steel. J Microb Biochem Technol 5: 068-073. doi:10.4172/1948-5948.1000102

Copyright: (c) 2013 Boretska M, et al. This is an open-access article distributed under the terms of the Creative Commons Attribution License, which permits unrestricted use, distribution, and reproduction in any medium, provided the original author and source are credited 
initially as a part of cell capsules which develop further in the biofilm formation process. Thus, EPS can be associated with surface attached biofilm cells or free-floating planktonic cells.

Structure and composition of EPS depend on many different factors. Structural components of EPS are biopolymers and biogenic minerals such as carbonates and sulfides, elemental sulfur as well as divalent cations such as $\mathrm{Ca}^{2+}$ or $\mathrm{Mg}^{2+}$. In the ferrosphere and in case of biofilms of acidophilic leaching bacteria on metal sulfides $\mathrm{Fe}^{2+}$ and $\mathrm{Fe}^{3+}$ have an important function $[6,18]$.

Due to the complex nature of EPS, there is no universal method for its chemical characterization. The latter also requires the application of different extraction methods regarding the type of EPS (capsular or loosely bound) and the physicochemical characteristics of the biofilm. There are two basic approaches for studying EPS. Chemical and physical extraction and analysis of the polymeric compounds from the bulk solution and cell surfaces or capsules can be distinguished from non-destructive probing of native EPS components. The latter can be analyzed by non invasive microscopical observations using specific probes [19]. Confocal Laser Scanning Microscopy (CLSM) allows the non-destructive three-dimensional investigation of fully hydrated and living structures and has been proven to be a very useful tool for the observation of biofilms and the distribution of EPS and cells on material surfaces [20].

The factors that mediate changes in the composition and distribution of the EPS directly impact material deterioration [18]. The influence of the substratum material itself on these processes may help to understand the role of EPS in MIC and help to develop new strategies for biocorrosion prevention. The objective of this study is the elucidation of the role of biocorrosion-inclined model surfaces, such as elemental sulfur or mild steel, on the EPS composition of Thiobacillus thioparus DSM 505 cells in either the planktonic or in the biofilm state.

\section{Materials and Methods}

\section{Bacterial strain and growth conditions}

Thiobacillus thioparus DSM 505 was cultivated using DSM 36 medium (Deutsche Sammlung von Mikroorganismen und Zellkulturen). $300 \mathrm{~mL}$ Erlenmeyer flasks with $100 \mathrm{~mL}$ medium were inoculated with $1 \times 10^{8}$ cells $/ \mathrm{mL}$ and cultivated for $3 \mathrm{~d}$ or $10 \mathrm{~d}$ at $30^{\circ} \mathrm{C}$ with $150 \mathrm{rpm}$ shaking.

\section{Substrate preparation}

Elemental sulfur as well as mild steel coupons were used as biocorrosion-inclined model surfaces. Elemental sulfur coupons were obtained by melting powdered elemental sulfur (Merck) on glass slide surfaces [21]. Afterwards, they were sterilized by autoclaving for 90 min at $110^{\circ} \mathrm{C}$, at 1.5 bar. Mild steel coupons (S235J2G3) were treated by degreasing solution as described [22]. Before inoculation treated for $30 \mathrm{~s}$ with $6 \mathrm{~N} \mathrm{H}_{2} \mathrm{SO}_{4}$ and added to T. thioparus cultures.

\section{Cell staining procedures and lectin binding assays}

Nucleic acids of planktonic and biofilm cells were stained with $0.01 \mathrm{w} / \mathrm{v} \%$ 4,6-diamidino-2-phenylindole (DAPI, Sigma) containing $2 \% \mathrm{v} / \mathrm{v}$ formaldehyde for $10 \mathrm{~min}$. The carbohydrate moieties present in EPS was visualized using lectins from Erythrina cristagalli (ECA), Canavalia ensiformis (ConA), Phytolacca americana (Pokeweed) (PWN), Glycine max (soybean) (SBA) and Arachis hypogaea (PNA) (Sigma) labeled with either tetramethylrhodamine isothiocyanate
(TRITC) or fluorescein isothiocyanate (FITC) as shown in Table 1. A solution of $50 \mu \mathrm{g} / \mathrm{ml}$ of each lectin was applied to the samples and they were incubated for $40 \mathrm{~min}$. Proteins were stained with a solution of $0.1 \mu \mathrm{g} / \mathrm{mL}$ Thiazine Red R (Sigma) containing $0.1 \% \mathrm{v} / \mathrm{v}$ acetic acid and applied by covering the samples for $30 \mathrm{~min}$. A laser scanning module (LSM 510 Carl Zeiss, Jena) coupled to an inverted Axiovert 100 MBP microscope (Zeiss) was used. All images were obtained with the planapochromatic 100X 0.79 oil DIC objective. For prolongation of the fluorescence of dyes the antifading agent CitiFluorTM AF2 was used. The microscope was operated with the software LSM 510 Release 3.2 (Carl Zeiss, Jena).

\section{Preparation of cells for microscopic observation}

Planktonic cells were quantified by cell counting with a Thoma chamber. For their microscopic observation $1 \mathrm{~mL}$ of culture medium was filtered through a polycarbonate filter (GTTB, diameter $0.25 \mathrm{~cm}$, $0.22 \mu \mathrm{m}$ pore size, Millipore). Subsequently, cells on the filters were washed, air dried and stained with fluorochrome dyes. After incubation of the coupons in the bacterial culture they were taken out, carefully washed with fresh medium to remove planktonic cells and particles for visualization of the biofilms. Afterwards, coupons were air dried and stained immediately by application of fluorochrome dyes, as described above.

\section{Extraction and analysis of Capsular EPS}

Cultures were centrifuged at $7000 \mathrm{rpm}$ for $10 \mathrm{~min}$ and cell pellets were diluted with $20 \mathrm{~mL}$ of PBS buffer $\left(2 \mathrm{mM} \mathrm{Na}_{3} \mathrm{PO}_{4}, 4 \mathrm{mM} \mathrm{NaH}_{2} \mathrm{PO}_{4}\right.$, $9 \mathrm{mM} \mathrm{NaCl}, 1 \mathrm{mM} \mathrm{KCl}$; pH 7). Extractions were done in PBS buffer for $4 \mathrm{~h}$ at $4^{\circ} \mathrm{C}$ and $100 \mathrm{rpm}$ using equivalent amounts of diluted cell pellets and cation exchange (CER) resin (DOWEX ${ }^{\mathrm{TM}}$ Marathon C, Sigma) previously treated with PBS buffer for $1 \mathrm{~h}$. Afterwards the aqueous phase was filtered through a glass filter funnel (Simax) and the filter was washed with $10 \mathrm{~mL}$ of PBS buffer to obtain EPS extract trapped within DOWEX beads. This EPS containing extract was centrifuged at $6000 \mathrm{rpm}$ for $5 \mathrm{~min}$, filtered through a $0.2 \mu \mathrm{m}$ pore size filter membrane and dialyzed against $\mathrm{ddH}_{2} \mathrm{O}$ using a $3.5 \mathrm{kDa}$ cutoff membrane tube (Sigma). Contamination of the extract by cells was checked by 2-keto3-deoxyoctonate analysis indicating cell membrane fragments [23]. The total carbohydrate content was measured using a phenol-sulfuric method according to Dubois [24]. Capsular EPS proteins were precipitated with trichloroacetic acid (TCA) [25] and analyzed by SDSPAGE (15\%), performed according to Laemmle [26].

\section{Verification of EPS detachment after extraction}

Verification of detachment of capsular EPS after cationic resin extraction treatment was done by transmission electron microscopy

\begin{tabular}{|l|l|l|}
\hline Lectin & Origin and specification & Fluorescent label \\
\hline ECA & $\begin{array}{l}\text { Erythrina cristagalli lectin } \\
\text { Galactose residues, the highest binding activity } \\
\text { toward galactosyl ( } \beta \text {-1,4)-N-acetylglucosamine }\end{array}$ & FITC (Sigma) \\
\hline ConA & $\begin{array}{l}\text { Canavalia ensiformis (Jack bean) seeds } \\
(\beta-1,3) \text { glycosidic bonds }\end{array}$ & TRITC/FITC (Sigma) \\
\hline PWM & $\begin{array}{l}\text { Phytolacca americana (Pokeweed) } \\
\text {-acetyl- } \beta \text {-D-glucosamine oligomers }\end{array}$ & FITC (Sigma) \\
\hline SBA & $\begin{array}{l}\text { Glycine max (soybean) seeds } \\
\text { terminal } \alpha \text { - or } \beta \text {-linked N-acetylgalactosamine }\end{array}$ & FITC (Sigma) \\
\hline PNA & $\begin{array}{l}\text { Arachis hypogaea } \\
\text { specific for terminal } \beta \text {-galactose, galactosyl ( } \beta-1,3) \\
\text { N-acetylgalactosamine }\end{array}$ & TRITC (Sigma) \\
\hline
\end{tabular}

Table 1: Specificity of lectins. 
(TEM). The floating drop method [27] was used with modifications for sample preparation. $1 \mathrm{~mL}$ of cell suspension before and after CER resin treatment was centrifuged ( $5 \mathrm{~s}, 2000 \mathrm{rpm})$ to remove sulfur particles. Subsequently, $10 \mu \mathrm{L}$ drops were placed on Parafilm sheets. Formvar copper coated grids were put on these drops. Cells were allowed to adhere for $10 \mathrm{~min}$; afterwards the grids were air-dried. Samples were observed using a TEM (Jeol 1400, Japan) at an accelerating voltage of $80 \mathrm{kV}$. For each sample 20 images were acquired.

\section{Results and Discussion}

Two experimental Corrosion scenarios were assayed using elemental sulfur (I) and mild steel surfaces (II). Their EPS properties were compared to features of cells and EPS form cells cultivated without these material surfaces. The ability of cells of T. thioparus DSM 505 to modify the composition of EPS in the planktonic and the biofilm state was analyzed.

\section{Corrosion scenario I (elemental sulfur coupon surface)}

Visualization of EPS from biofilms on the elemental sulfur coupon surface showed cell surface polysaccharide binding with three lectins on $3 \mathrm{~d}$ and $10 \mathrm{~d}$ after inoculation. PWM, ECA and SBA-lectin signals were observed indicating the presence of poly- $\mathrm{N}$-acetyl-glucosamine (PNAG) residues, galactosyl $(\beta-1,4)$-poly- $\mathrm{N}$-acetylglucosamine and terminal $\alpha$ - or $\beta$-linked $\mathrm{N}$-acetyl galactosamine residues, respectively (Figure 1a). In contrast to sessile cells, planktonic cells cultivated for a period of $3 \mathrm{~d}$ in the presence of elemental sulfur coupons produced EPS, which reacted only with the PWM lectin (Figure 1b) with comparable signal intensity $10 \mathrm{~d}$ after inoculation. The diversity of carbohydrate moieties present in biofilm-derived EPS, which are not present in EPS of planktonic cells, including the presence of galactose in biofilm EPS is in agreement with previous data obtained by a GC-MS method [15].

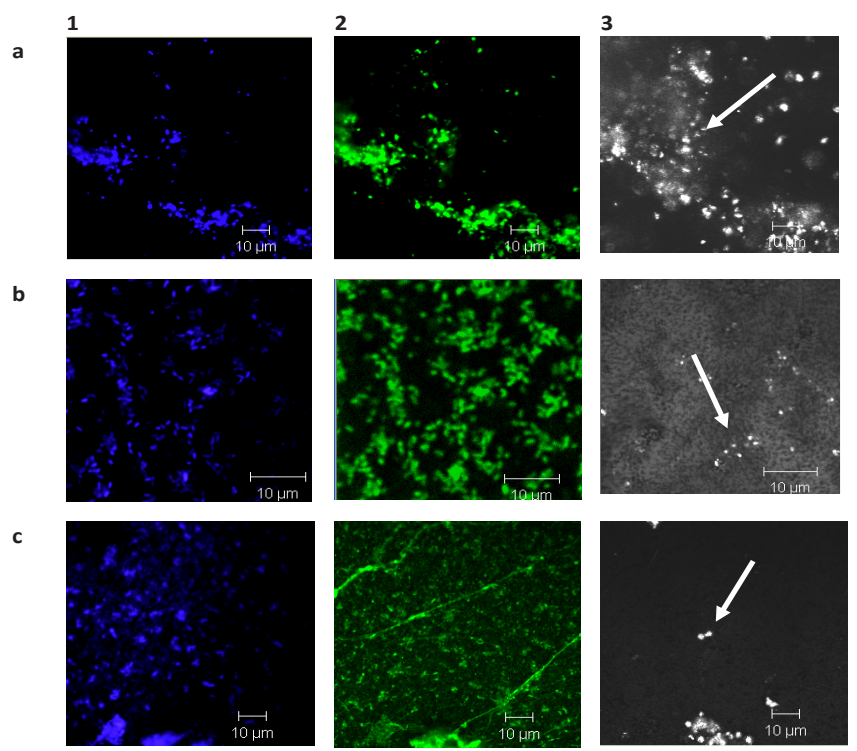

Figure 1: PWM-lectin reveals presence of poly-N-acetyl-glucosamine (PNAG) moieties in EPS of Thiobacillus thioparus DSM 505 after growth in presence of sulfur or steel surfaces. Cells were grown at $28^{\circ} \mathrm{C}$ with shaking at $120 \mathrm{rpm}$. A biofilm structure formed on a sulfur coupon after $3 \mathrm{~d}$ (a), planktonic cells from the same culture filtered on polycarbonate filters (b) and a biofilm structure formed on a mild steel surface after $10 \mathrm{~d}(\mathbf{c})$ are shown. Fluorescence signal of the nucleic acid specific fluorochrome DAPI (1) is shown separately from FITClabeled PWM lectin signal (2) and surface reflection signal (3) of sulfur particles (arrows). Size bars represent $10 \mu \mathrm{m}$.
Thus, applied lectins revealed differences in the EPS compositions corresponding with alternative growth modes of T. thioparus.

\section{Corrosion scenario II (mild steel coupon surface)}

EPS of biofilms on mild steel surfaces showed binding only of the PWM and SBA lectins after $3 \mathrm{~d}$ and $10 \mathrm{~d}$ of cultivation. Structural features visible as strands of EPS from biofilms on the steel surface rich in PNAG were observed after $10 \mathrm{~d}$ of cultivation using the PWM lectin (Figure 1c). PNAG is a major factor of adhesion to hydrophobic polystyrene surfaces by Aggregatibacter actinomycetemcomitans [28] Thus, we can suggest a similar attachment mechanism that determines adhesion to hydrophobic sulfur particles in soil. The EPS of planktonic cells cultivated for a period of $3 \mathrm{~d}$ and $10 \mathrm{~d}$ in the presence of steel coupons could only be stained and visualized with the PWM-lectin.

It should be noted that in the presence of elemental sulfur the synthesis of galactosyl $(\beta-1,4)$-poly- $\mathrm{N}$-acetylglucosamine was stimulated. Obviously, this is related with a metabolic change of $T$. thioparus in the presence of elemental sulfur surfaces.

\section{Control scenario (absence of sulfur or steel surface)}

Planktonic cells cultivated without any additional materials surface showed the presence of glucose or mannose residues in the EPS as revealed by the lectin ConA binding to $\beta-1,3$ glycosidic bonds in mannose and glucose rich capsule material (Figure 2). Binding of this lectin was not observed in case of planktonic or biofilm cells in model corrosion scenarios. This finding suggests specific modifications of the EPS polysaccharide composition in the presence of iron ions or sulfur compounds. In our Control scenario the process of thiosulfate oxidation provides energy for growth and the carbohydrate expression seems to be regulated in a different way in absence of a solid substratum. PWM-, ECA- and SBA-lectin binding signals were not detectable for capsule polysaccharides of such planktonic cells.

The PNA lectin, which binds specifically to terminal $\beta$-galactose or galactosyl $(\beta-1,3) \mathrm{N}$-acetylgalactosamine did not bind to the EPS under any of the described conditions. This strongly indicates a lack of this sugar moiety in the EPS produced by T. thioparus DSM 505 under these conditions.

It is shown that corrosive metabolic activity influences the EPS composition, which can be observed after lectin staining of biofilms grown on sulfur and steel surfaces. Thus, the presence of elemental sulfur can stimulate the capsular EPS and PNAG production in $T$. thioparus DSM 505. The regulatory mechanisms presumably exerted by soluble corrosion products affecting the compositional modification of EPS remain to be elucidated in detail. However, this switch may play an important role in subsequent attachment of planktonic cells to surfaces, presumably promoting corrosion relevant reactions on the material surface.

EPS compounds belong to different classes of macromolecules $[16,29,30]$. According to these authors, the microbial attachment to solid surfaces is affected by the protein structure and the molecular interactions between conjugative pili and surfaces. Elimination of the outer protein layer from cells caused significant (even 100 times) reduction of Streptococcus spp. and Bacillus spp. adhesion to the stainless steel surfaces. For observing proteins produced by T. thioparus DSM 505 Thiazine Red staining was used. The protein distribution was visualized with planktonic cells cultivated in the presence of mild steel and elemental sulfur (Figure 3). 
As capsular exopolymers of planktonic cells are determining the initial attachment stage of biofilm formation [31], these compounds were examined more closely by extraction and chemical analysis. The effectiveness of extraction of such capsular material was visualized by electron microscopy (Figure 4). Microscopic observation revealed a capsule surrounding planktonic cells. After treatment with CER the extracellular capsule layer was obviously removed from the cells. This treatment was therefore considered sufficient for detachment of capsular material from cells and suitable for its subsequent chemical analysis.
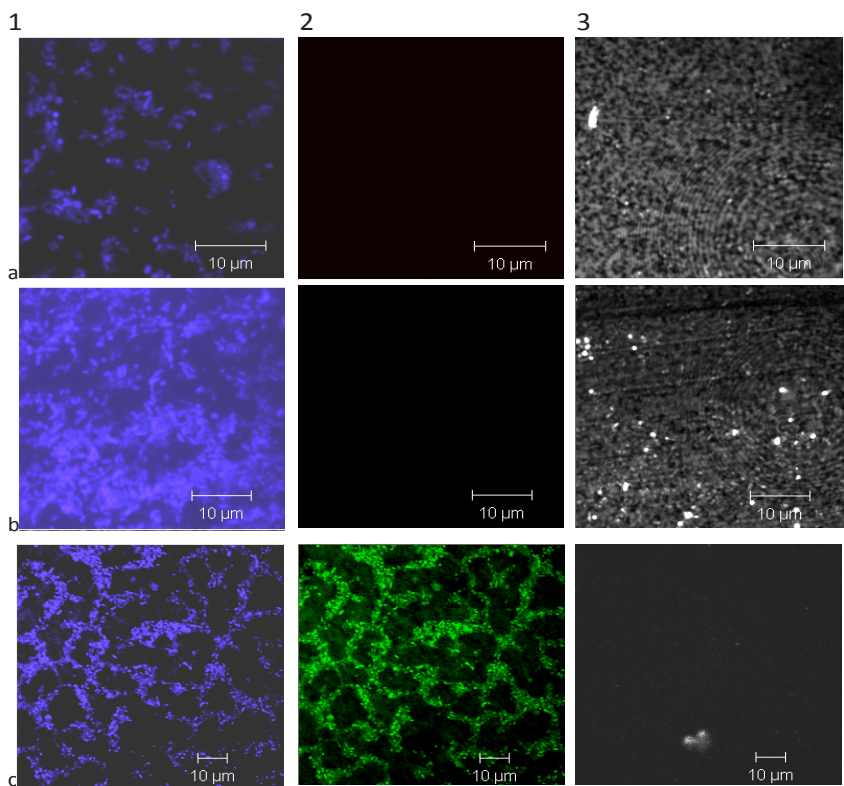

Figure 2: ConA lectin does not bind to cells of Thiobacillus thioparus DSM 505 grown in presence of mild steel or elemental sulfur. Cells were grown at $28^{\circ} \mathrm{C}$ with shaking at $120 \mathrm{rpm}$. Planktonic cells cultivated for 10 days in presence of mild steel (a), elemental sulfur (b) and planktonic cells incubated without steel or sulfur coupons (c) are shown. Cells were filtered on a polycarbonate membrane and stained with the nucleic acid specific fluorochrome DAPI (1) and FITClabeled ConA lectin (2). Surface light reflection signal is shown in (3). Size bars represent $10 \mu \mathrm{m}$
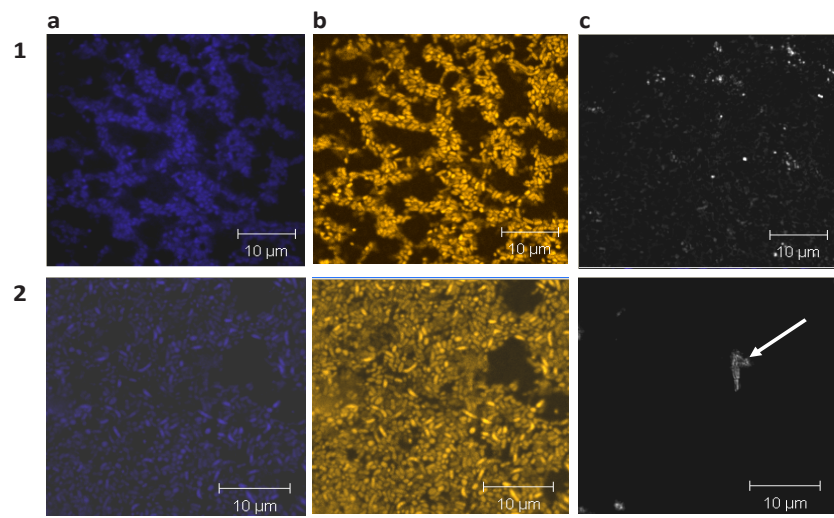

Figure 3: Protein visualization of planktonic cells of Thiobacillus thioparus DSM 505 in presence of mild steel (1) and elemental sulfur coupons (2) after $3 \mathrm{~d}$. Planktonic cells were transferred on a polycarbonate filter $(0.22 \mu \mathrm{m}$ poresize $)$ and subsequently stained with the nucleic acid specific dye DAPI (a) and the protein stain Thiazine Red (b). Reflection signal from e.g. sulfur particles (arrow) are shown in c. Size bars represent $10 \mu \mathrm{m}$.

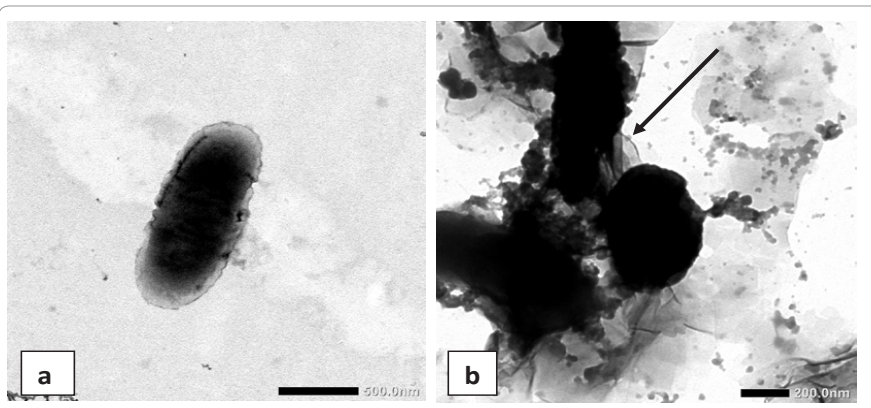

Figure 4: Removal of capsular exopolymeric substances from planktonic cells of Thiobacillus thioparus DSM 505. $100 \mu \mathrm{L}$ drop of sample was applied to the copper grid with Formvar ${ }^{\circledR}$ layer $(\mathbf{A})$. The removal of the capsular polymer layer was demonstrated after cationic exchange resin treatment $(\mathbf{B})$ by TEM.

The carbohydrate amount of capsular EPS from planktonic cells cultivated in the presence of different surfaces was analyzed (Table 2). The maximum amount of total carbohydrates $\left(174 \mu \mathrm{g} / 10^{8}\right.$ cells $)$ in capsular EPS $3 \mathrm{~d}$ after inoculation was detected in the Control scenario, where reactive steel or sulfur surfaces were absent. According to our previous data [32], which correlated with lectin binding tests, such kind of polysaccharides as a major fraction of the EPS consisted mostly of glucose (34\% from total neutral carbohydrates). Planktonic cells in the Control scenario and Corrosion scenario I on the $3^{\text {rd }}$ and $10^{\text {th }}$ day after inoculation were equal $\left(2 \times 10^{8}\right.$ cells $\left./ \mathrm{mL}\right)$. This may be explained by a presence of elemental sulfur as it may occur as an intermediate during thiosulfate oxidation. In the same time the amount of planktonic cells in the Corrosion scenario II significantly declined (from $0.5 \pm 0.1 \times 10^{8}$ to $0.1 \pm 0.2 \times 10^{8}$ cells $/ \mathrm{mL}$ ). This could be connected with metal surface colonization and active solubilization of metal ions, which would correlate with our previous data [22]. The highest amount of total carbohydrates in the capsular EPS in this sample after $10 \mathrm{~d}$ of cultivation could be related with a chemotaxis process. The cells were attaching efficiently to the steel coupon. The attraction due to solubilized metals from the steel surface is presumably followed by a synthesis of a capsule containing required adhesins and metal complexing carboxyl group residues [6]. Electrostatic interactions mediated by complexed metal ions in EPS is a described initial attachment mechanism $[6,16]$.

Extracellular secreted proteins with molecular masses between 10 and $200 \mathrm{kDa}$ contain 40 to $60 \%$ of hydrophobic amino acids [33]. For determining the molecular weight of the proteins in the capsular EPS of T. thioparus DSM 505 SDS-PAGE was used. Medium weight proteins of 60 to $80 \mathrm{kDa}$ were detected in EPS extracts from planktonic cells (Figure 5). Two distinct bands of proteins were detected in capsular EPS from planktonic cells originating from the Control scenario, detected by SDS-PAGE, after 3 and 10 days. Besides of increasing planktonic cell numbers during the cultivation period the amount of protein in the SDS-PAGE gel after 10 days of cultivation did not differ from those observed after 3 days. In presence of elemental sulfur coupon surfaces in the Corrosion scenario I higher amounts and a more complex pattern of EPS proteins compared to those observed in the Control scenario were detected. Also with the proceeding cultivation period after 10 days the pattern differed from the one observed after 3 days. Hence, an increase in the planktonic cell number correlated with higher amounts of protein after $10 \mathrm{~d}$. Further investigations concerning these protein bands and the planktonic and the biofilm cell subpopulations will presumably provide further insights in the 


\begin{tabular}{|l|c|c|}
\hline Type of surface & $\begin{array}{c}\text { Cells number } \\
\text { during } \\
\text { experiment }\left(\times \mathbf{1 0}^{8}\right)\end{array}$ & $\begin{array}{c}\text { Total } \\
\text { carbohydrates } \\
\text { in capsular } \\
\text { EPS } \\
\left(\mathbf{\mu g} / \mathbf{1 0}^{\mathbf{8}} \text { cells) }\right.\end{array}$ \\
\hline $\mathbf{3}$ d after inoculation & $1,06 \pm 0,23$ & 148 \\
\hline $\begin{array}{l}\text { Corrosion scenario I } \\
\text { (sulfur) }\end{array}$ & $0,54 \pm 0,12$ & 164 \\
\hline $\begin{array}{l}\text { Corrosion scenario II } \\
\text { (steel) }\end{array}$ & $0,73 \pm 0,08$ & 174 \\
\hline Control scenario (without of surface) & & \\
\hline $\mathbf{1 0}$ d after inoculation & $2,21 \pm 0,14$ & 142 \\
\hline $\begin{array}{l}\text { Corrosion scenario I } \\
\text { (sulfur) }\end{array}$ & $0,14 \pm 0,2$ & 155 \\
\hline $\begin{array}{l}\text { Corrosion scenario II } \\
\text { (steel) }\end{array}$ & $2,03 \pm 0,18$ & 136 \\
\hline Control scenario (without of surface) & & \\
\hline
\end{tabular}

Table 2: Characterization of capsular exopolymeric substances of Thiobacillus thioparus DSM 505 in planktonic cells.

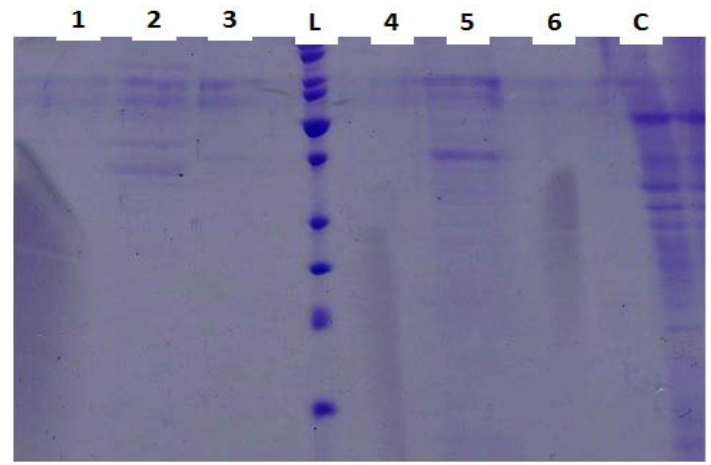

Figure 5: SDS-PAGE of proteins present in capsular EPS extracted with Dowex cation exchange resin from planktonic cells of Thiobacillus thioparus DSM 505. Capsular proteins of cells from the Control scenario $(1,4)$, the Corrosion scenario $\mathrm{I}(\mathbf{2}, \mathbf{5})$ and the Corrosion scenario II $(3,6)$ are shown. Lanes $\mathbf{1}, \mathbf{2}$ and $\mathbf{3}$ show proteins in capsular EPS from cells $3 \mathrm{~d}$ after inoculation, while lanes $\mathbf{4 , 5}$ and 6 show proteins of capsular material after $10 \mathrm{~d}$ incubation. Lane $\mathbf{L}$ contains a protein size ladder for the range of 30 to $80 \mathrm{kDa}$. Lane $\mathrm{C}$ shows cell crude extract proteins for comparison with proteins from capsular EPS in lanes 1 to 6.

molecular processes that mediate attachment to elemental sulfur. We can suggest that presumably due to attachment and biofilm formation those cells remain in the free-swimming, planktonic state which lack effectual proteinaceous capsular material that mediates attachment to hydrophobic substrata such as elemental sulfur. In general, low amounts of EPS proteins were detected in the Control scenario, were a reactive surface, such as elemental sulfur or mild steel was not present. Analogously, in the Corrosion scenario II (mild steel) low amounts of proteins were detected and a decrement of the planktonic cellnumber was attended by a decrease of the amounts of capsular proteins observed after 3 and $10 \mathrm{~d}$, respectively. The variety and the abundance of capsular proteins detected by SDS-Page in presence of elemental sulfur is significantly different from those observed in the other assays. These proteins will be studied further to determine their annotated functions and to relate their abundance. Further on these functions can be related to processes such as attachment and electron transfer, to elucidate their role in the biocorrosion process. The latter of special importance will be those EPS proteins which are expressed in the biofilm cell subpopulation.

\section{Concluding Remarks}

In this study the influence of steel and elemental sulfur surfaces on the EPS composition of T. thioparus is shown. Sulfur compounds present in soil habitats and in the ferrosphere are hydrogen sulfide, polysulfides, elemental sulfur and sulfate [34]. These compounds are formed due to metabolic activity of sulfur cycle bacteria. The Thiobacillus/Acidithiobacillus genera are widespread in soil, rock, mine and water econiches and according to [7], geochemical activity of these thionic bacteria is closely linked with sulfur generation during the oxidation of biogenic hydrogen sulfide. The latter is produced by sulfate reducing bacteria. The contribution of sulfur cycle bacteria to the corrosion of underground constructions has been shown already in the 1930s by C.H. Kühr and L.S. van Der Vlugt [7]. The corrosive activity of elemental sulfur is established in corrosion research and its influence on biofilms of T. thioparus and their EPS properties has been addressed in this study. However, not only elemental sulfur, but also generation of sulfuric acid is responsible for the corrosive metabolic activity of T. thioparus. As mentioned [8], sulfuric acid increases the solubility of metal ions and other corrosion products. These corrosion products, such as iron ions seem to mediate a specific modification of the capsular EPS composition, enabling cells to attach efficiently to metallic surfaces. Structural features rich in PNAG residues in biofilms on steel could be visualized and their presence suggests a specific function in the biocorrosion process, as these structures and the sugar moieties were not observed in biofilms on elemental sulfur. Thus, our comparative corrosive scenario model allows us to elucidate interrelationships between biominerals such as elemental sulfur and biopolymer compounds in EPS, which are present in the ferrosphere near pipelines or other metal constructions. Our results indicate that the EPS composition is changing after exposure of cells to elemental sulfur or to mild steel surfaces. A more close investigation in the future regarding sulfur content and a determination of the soil aggressiveness regarding underground metal constructions is suggested. Thus biogenic sulfur and metal ions released during initial corrosion processes can be suggested to act as an intrinsic stimulant of EPS matrix modification of corrosion-relevant bacteria.

\section{Acknowledgment} 2012]

This research was partly supported by the FEMS Fellowship Grant [2011-

\section{References}

1. Wimpenny J, Manz W, Szewzyk U (2000) Heterogeneity in biofilms. FEMS Microbiol Rev 24: 661-671.

2. Parsek MR, Singh PK (2003) Bacterial biofilms: an emerging link to disease pathogenesis. Annu Rev Microbiol 57: 677-701.

3. Moshynets OV, Shpylova SP, Kordium VA, Potters G (2012) Visualisation of endophytic bacteria in Phyllostachys sp. and Fargesia sp. Bamboo Science and Culture 25: 11

4. Robertson M, Hapca SM, Moshynets O, Spiers AJ (2013) Air-liquid interface biofilm formation by psychrotrophic pseudomonads recovered from spoilt meat Antonie Van Leeuwenhoek 103: 251-259.

5. Karatan E, Watnick $P$ (2009) Signals, regulatory networks, and materials that build and break bacterial biofilms. Microbiol Mol Biol Rev 73: 310-347.

6. Beech IB, Sunner J (2004) Biocorrosion: towards understanding interactions between biofilms and metals. Curr Opin Biotechnol 15: 181-186.

7. Andreyuk Kl, Kozlova IP, Kopteva ZhP (2005) Microbiall corrosion of underground constructions (ukr). Naukova Dumka.

8. Sokolova GA, Karavaiko GI (1964) Phiziologiya yi geochimicheskaya 
Citation: Boretska M, Bellenberg S, Moshynets O, Pokholenko I, Sand W (2013) Change of Extracellular Polymeric Substances Composition of Thiobacillus thioparus in Presence of Sulfur and Steel. J Microb Biochem Technol 5: 068-073. doi:10.4172/1948-5948.1000102

dejatelnost thionovyh bacterij (Phiziology and geochemistry activities of thionic bacteria) (rus). Nauka.

9. Katayama Y, Matsushita Y, Kaneko M, Kondo M, Mizuno T, et al. (1998) Cloning of genes coding for the three subunits of thiocyanate hydrolase of Thiobacillus thioparus THI 115 and their evolutionary relationships to nitrile hydratase. J Bacteriol 180: 2583-2589.

10. Starkey RL (1937) Formation of Sulfide by Some Sulfur Bacteria. J Bacteriol 33: $545-571$.

11. Alcántara S, Velasco A, Revah S (2004) Sulfur formation by steady-state continuous cultures of a sulfoxidizing consortium and Thiobacillus thioparus ATCC 23645. Environ Technol 25: 1151-1157.

12. Booth GH (1964) Sulphur Bacteria in Relation to Corrosion. J Appl Microbiol 27: 174-181.

13. Flemming HC, Wingender J (2010) The biofilm matrix. Nat Rev Microbiol 8: 623-633.

14. Dinh HT, Kuever J, Mussmann M, Hassel AW, Stratmann M, et al. (2004) Iron corrosion by novel anaerobic microorganisms. Nature 427: 829-832.

15. Borets'ka MO, Kozlova IP (2010) Biofilm on a metal surface as a factor of microbial corrosion. Mikrobiol Z 72: 57-65.

16. Gehrke T, Telegdi J, Thierry D, Sand W (1998) Importance of Extracellular Polymeric Substances from Thiobacillus ferrooxidans for Bioleaching. Appl Environ Microbiol 64: 2743-2747.

17. O'Toole G, Kaplan HB, Kolter R (2000) Biofilm formation as microbial development. Annu Rev Microbiol 54: 49-79.

18. Rohwerder T, Gehrke T, Kinzler K, Sand W (2003) Bioleaching review part A: progress in bioleaching: fundamentals and mechanisms of bacterial metal sulfide oxidation. Appl Microbiol Biotechnol 63: 239-248.

19. Wingender J, Neu TR, Flemming HC (1999) Microbial extracellular polymeric substances: characterization, structure and function. Springer-Verlag.

20. Neu TR, Manz B, Volke F, Dynes JJ, Hitchcock AP, et al. (2010) Advanced imaging techniques for assessment of structure, composition and function in biofilm systems. FEMS Microbiol Ecol 72: 1-21.

21. Bellenberg S, Leon-Morales C-F, Sand W, Vera M (2012) Visualisation of capsular polysaccharide induction in Acidithiobacillus ferroxidans Hydrometallurgy 129-130: 82-89.

22. Borets'ka MO, Kozlova IP (2007) Effect of the biofilm biopolymers on the microbial corrosion rate of the low-carbon steel. Mikrobiol Z 69: 40-44.

23. Karkhanis YD, Zeltner JY, Jackson JJ, Carlo DJ (1978) A new and improved microassay to determine 2-keto-3-deoxyoctonate in lipopolysaccharide of Gram-negative bacteria. Anal Biochem 85: 595-601.

24. Dubois M, Gilles KA, Hamilton JK, Rebers PA, Smith F (1956) Colorimetric method for determination of sugars and related substances. Anal Chem 28 : 350-356.

25. Maniatias T, Fritsh EF, Sambrook J (1982) Molecular Cloning: a Laboratory Manual. Cold Spring Harbor Laboratory.

26. Laemmle UK (1970) Cleavage of structural proteins during the assembly of the head of bacteriophage T4. Nature 227: 680-685.

27. Burghardt RC, Droleskey R (2006) Transmission electron microscopy. Current Protocols in Microbiology 3: 2B.1.1-2B.1.39.

28. Izano EA, Sadovskaya I, Wang H, Vinogradov E, Ragunath C, et al. (2008) Poly-N-acetylglucosamine mediates biofilm formation and detergent resistance in Aggregatibacter actinomycetemcomitans. Microb Pathog 44: 52-60.

29. Sutherland IW (2001) Microbial polysaccharides from Gram-negative bacteria Int Dairy J 11: 663-674.

30. Branda SS, Vik S, Friedman L, Kolter R (2005) Biofilms: the matrix revisited. Trends Microbiol 13: 20-26.

31. Neu TR (1996) Significance of bacterial surface-active compounds in interaction of bacteria with interfaces. Microbiol Rev 60: 151-166.

32. Borets'ka MO, Ostapchuk AM, Kozlova IP (2007) Monosaccharide composition of exopolymer complex in Thiobacillus thioparus and Stenotrophomonas maltophilia. Ukr Biokhim Zh 79: 140-144.

33. Lory S (1992) Determinants of extracellular protein secretion in gram-negative bacteria. J Bacteriol 174: 3423-3428.

34. Ehrlich H (2008) Geomicrobiology. ( $5^{\text {th }}$ edn) CRC Press Taylor \& Francis Group. 